\title{
Ekstrak Metanol Daun Binahong (Anredera cordifolia) Menekan Pertumbuhan Koloni Jamur Rhizoctonia oryzae dan Kejadian Penyakit Hawar Bibit Padi
}

\author{
Endah Yulia ${ }^{*}$, Elga Sari ${ }^{2}$, Sudarjat ${ }^{1}$, Fitri Widiantini ${ }^{1}$, dan Ida Nurhelawati ${ }^{3}$ \\ ${ }^{1}$ Departemen Hama dan Penyakit Tumbuhan, Fakultas Pertanian, Universitas Padjadjaran \\ ${ }^{2}$ Progam Studi Agroteknologi, Fakultas Pertanian, Universitas Padjadjaran \\ ${ }^{3}$ Program Studi Magister Agronomi, Fakultas Pertanian, Universitas Padjadjaran \\ Kampus Jatinangor KM 21 Jatinangor 45363 \\ *Alamat korespondensi: endah.yulia@unpad.ac.id
}

\begin{abstract}
Binahong (Anredera cordifolia) methanol leaf extract suppressed colony growth of Rhizoctonia oryzae and seedling blight disease of paddy
\end{abstract}

\begin{abstract}
Sheath spot disease caused by Rhizoctonia oryzae is one of important diseases in rice plants. This disease is generally controlled by using synthetic fungicides, although this control method is believed to have negative impacts on the environment and human health. Thus, at this time it has become a concern to implement more environmentally friendly control methods, one of which is through the use of natural materials such as plants as plant-based pesticides. Binahong plants (Anredera cordifolia) has been widely used as traditional medicine, especially in the field of human health. This study aims were to examine the effectiveness of binahong leaf extract in suppressing the growth of $R$. oryzae colonies and the development of seed blight disease on rice seeds due to $R$. oryzae infection. The experiment was carried out at the Biotechnology Laboratory, Department of Plant Pests and Diseases, Faculty of Agriculture, Universitas Padjadjaran. The research method used was a Completely Randomized Design (CRD) consisting of 7 treatments (extract concentrations of $0.25 \%, 0.5 \%, 1 \%, 1.5 \%$, and $2 \%$; control without extract; and fungicide propineb $0.3 \%$ ) and 4 replications for the inhibition of colony growth of $R$. oryzae test using poisoned food technique. Seed treatment test was carried out with 4 treatments and 5 replications, each consisting of 25 rice seeds using immersion technique. The results showed that the metanol extract of binahong leaf $2 \%$ was able to inhibit the growth of the colony and the formation of sclerotia of $R$. oryzae. The results of seed treatment testing showed that binahong leaf methanol extract $2 \%$ had ability in suppressing the incidence of seed and seedling disease due to $R$. oryzae infection with the highest suppression of disease incidence by $46.2 \%$.
\end{abstract}

Keywords: Botanical pesticide, Damping-off, Rhizoctonia sp., Sheath spot

\section{ABSTRAK}

Penyakit bercak pelepah yang disebabkan oleh Rhizoctonia oryzae merupakan salah satu penyakit penting pada tanaman padi. Sementara itu, pada bibit padi jamur Rhizoctonia sp. dapat mengakibatkan penyakit rebah kecambah atau hawar bibit. Penyakit ini umumnya dikendalikan dengan menggunakan fungisida sintetik meskipun pengendalian cara ini diketahui dapat memberikan efek negatif terhadap lingkungan dan kesehatan manusia. Dalam upaya pengembangan pengendalian penyakit tanaman yang lebih ramah lingkungan, pemanfaatan bahanbahan alami seperti tumbuhan sebagai pestisida nabati telah mendapat banyak perhatian pada saat ini. Tanaman binahong (Anredera cordifolia) telah banyak digunakan sebagai obat tradisional terutama di bidang kesehatan manusia. Penelitian ini bertujuan untuk menguji keefektifan ekstrak metanol daun binahong dalam menekan pertumbuhan koloni jamur $R$. oryzae serta menekan kejadian penyakit hawar bibit pada benih padi akibat infeksi $R$. oryzae. Percobaan dilakukan di 
Laboratorium Bioteknologi Proteksi Tanaman, Departemen Hama dan Penyakit Tumbuhan, Fakultas Pertanian, Universitas Padjadjaran. Metode penelitian menggunakan Rancangan Acak Lengkap (RAL). Pengujian penghambatan pertumbuhan koloni jamur $R$. oryzae dilakukan menggunakan teknik poisoned food dengan tujuh perlakuan yaitu lima konsentrasi ekstrak 0,25\%, 0,5\%, 1\%, 1,5\%, dan 2\%, serta perlakuan kontrol akuades steril dan fungisida propineb 0,3\% yang diulang empat kali. Pengujian pada benih dilakukan dengan empat perlakuan yaitu ekstrak konsentrasi $2 \%$, Tween-80 0,2\%, propineb 0,3\% dan akuades steril yang diulang lima kali. Masingmasing perlakuan terdiri atas 25 benih padi menggunakan teknik perendaman. Hasil pengujian menunjukkan ekstrak metanol daun binahong 2\% mampu menghambat pertumbuhan koloni dan pembentukan sklerotia jamur $R$. oryzae serta mampu menekan kejadian penyakit akibat infeksi $R$. oryzae pada bibit padi dengan penekanan tertinggi sebesar $46,2 \%$.

Kata Kunci: Bercak pelepah, Rebah kecambah, Pestisida nabati, Rhizoctonia sp.

\section{PENDAHULUAN}

Penyakit bercak pelepah merupakan salah satu penyakit penting pada tanaman padi (Lanoiselet et al., 2005). Penyakit ini disebabkan oleh jamur Rhizoctonia oryzae dengan gejala penyakit berupa lesi atau bercak pada pelepah daun padi (Aye \& Matsumoto, 2012; Guo et al., 2006). Gejala ini mirip dengan gejala lesi penyakit hawar pelepah daun padi akibat infeksi jamur Rhizoctonia solani tetapi ukurannya lebih kecil dan memiliki batas bercak yang jelas berwarna coklat tua, serta tidak bersatu. Jamur $R$. oryzae merupakan patogen yang ditularkan melalui tanah (Aye \& Matsumoto, 2012). Infeksi jamur $R$. oryzae dapat mengakibatkan tanaman padi menjadi kerdil dan mati sebelum waktunya (Paulitz et al., 2003; Nagaraj et al., 2019). Jamur Rhizoctonia sp. juga dapat mengakibatkan penyakit rebah kecambah (damping-off) atau hawar bibit pada bibit tanaman padi (Groth \& Hollier, 2010).

Penyakit bercak pelepah pertama kali dilaporkan di Amerika Serikat pada tahun 1984 pada tanaman gandum dan kemudian penyakit dilaporkan menyebar luas ke kawasan California, Australia, India, Italia, Bangladesh, Uruguay serta kawasan Asia Tenggara (Lanoiselet et al., 2007). Jamur $R$. oryzae dilaporkan menyerang beberapa kultivar padi di Myanmar selain serangan dari spesies Rhizoctonia yang lain (Aye et al., 2009). Sementara itu, di Indonesia tingkat serangan dan kehilangan hasil akibat $R$. oryzae belum banyak dilaporkan berbeda dengan akibat $R$. solani.

Pengendalian penyakit pada tanaman padi umumnya dilakukan secara kimiawi dengan menggunakan pestisida sintetik. Hasil yang cepat dan ketersediaan pestisida yang selalu ada serta mudah diperoleh menjadi alasan petani untuk memilih pengendalian secara kimiawi ini. Namun demikian, pengendalian secara kimiawi diketahui memiliki efek yang kurang baik terhadap lingkungan sehingga beberapa alternatif pengendalian seperti penggunaan pestisida nabati mulai menjadi kajian untuk pengendalian yang lebih ramah lingkungan.

Salah satu tanaman yang dapat dijadikan sumber pestisida nabati adalah tanaman binahong (Anredera cordifolia (Ten.) Steenis) (Rimporok dkk., 2015). Tanaman binahong dilaporkan banyak mengandung senyawa bioaktif seperti alkaloid, polifenol, flavonoid, saponin, terpenoid, steroid, glycosides, dan antrakuinon (Kumalasari \& Sulistyani, 2011). Tanaman ini sudah banyak digunakan sebagai tanaman obat oleh masyarakat di berbagai negara. Kemampuan ekstrak tanaman binahong di dalam menghambat patogen tanaman telah ditunjukkan pada penghambatan pertumbuhan koloni jamur Colletotrichum spp. dan Fusarium oxysporum dengan menggunakan ekstrak air daun binahong (Widiantini dkk., 2016; Yulia dkk., 2016). Ekstrak metanol daun binahong juga dilaporkan mampu menekan perkembangan penyakit hawar bibit padi akibat infeksi $R$. solani (Yulia \& Widiantini, 2018). Penelitian ini bertujuan untuk memperoleh keefektifan ekstrak metanol daun binahong di dalam menghambat pertumbuhan koloni jamur $R$. oryzae serta menekan kejadian penyakit akibat $R$. oryzae pada bibit padi.

\section{BAHAN DAN METODE}

Penelitian dilakukan pada bulan Maret - Juli 2019 di Laboratorium Bioteknologi Proteksi Tanaman, Departemen Hama dan penyakit Tumbuhan, Fakultas Pertanian, Universitas Padjadjaran. Percobaan dilakukan dengan menggunakan metode eksperimen Rancangan Acak 
Lengkap (RAL) dengan pengujian keefektifan ekstrak metanol daun binahong terhadap patogen $R$. oryzae secara in vitro pada lima konsentrasi ekstrak metanol daun binahong yaitu $0,25 \%, 0,5 \%, 1 \%$, $1,5 \%$ dan $2 \%$, perlakuan fungisida propineb $0,3 \%$ (kontrol negatif), serta perlakuan tanpa ekstrak (kontrol positif) sehingga terdapat tujuh perlakuan yang masing-masing diulang sebanyak empat kali. Pengujian pada benih terdiri atas empat perlakuan yaitu perlakuan ekstrak dengan konsentrasi paling efektif di perlakuan sebelumnya, Tween-80 0,2\%, propineb $0,3 \%$ dan akuades steril yang diulang lima kali. Data yang diperoleh dianalisis statistik menggunakan program SPSS versi 22. Analisis data dilakukan menggunakan ANOVA, apabila terdapat pengaruh perlakuan maka dilakukan Uji Lanjut Duncan pada taraf nyata $5 \%$.

\section{Isolasi Patogen Rhizoctonia oryzae}

Jamur $R$. oryzae diisolasi dari pelepah daun tanaman padi yang menunjukkan gejala bercak pada pelepah padi. Pelepah daun dipotong di antara bagian yang sehat dan yang bergejala. Potonganpotongan kecil tersebut dicelupkan selama 15 detik ke dalam larutan alkohol $70 \%$ yang kemudian direndam pada larutan sodium hipoklorit 1\% selama lima menit. Potongan pelepah daun yang sudah didisinfeksi tersebut dibilas sebanyak tiga kali dengan menggunakan akuades steril dan kemudian dikeringkan dengan menempatkannya pada kertas saring steril. Setelah itu, potongan daun tersebut diletakkan pada media tumbuh Potato Dextrose Aga (PDA) dan diinkubasikan pada suhu ruang $\left( \pm 28^{\circ} \mathrm{C}\right)$. Miselium yang tumbuh kemudian dipindahkan ke media PDA yang baru sebagai biakan murni. Jamur $R$. oryzae yang sudah ditumbuhkan pada media PDA ini kemudian diinkubasi pada suhu ruang sampai digunakan di dalam percobaan.

\section{Pembuatan Ekstrak Metanol Daun Binahong}

Pembuatan ekstrak metanol daun binahong dilakukan dengan metode maserasi. Daun binahong dikumpulkan dan dicuci bersih. Daun binahong yang telah bersih kemudian dikeringudarakan selama satu hari di meja laboratorium. Setelah dikeringudarakan, daun binahong dikeringkan di dalam pengering kabinet/oven pada suhu $45-60^{\circ} \mathrm{C}$ untuk menghilangkan kadar air pada daun (Astuti, 2011). Daun binahong yang sudah kering kemudian disiapkan dalam bentuk serbuk menggunakan mesin penggiling. Setelah itu, serbuk daun binahong sebanyak $100 \mathrm{~g}$ dimaserasi dengan menggunakan pelarut metanol teknis (1 liter) selama $3 \times 24$ jam. Bobot perbandingan yang digunakan adalah 1:5 (w/v) untuk perbandingan bobot bahan dan pelarut. Setelah dilakukan maserasi/perendaman tersebut, selanjutnya dilakukan penyaringan dengan menggunakan kertas saring yang diletakkan pada corong. Hasil penyaringan ini diuapkan dengan rotary evaporator pada suhu $55-60^{\circ} \mathrm{C}$ dan penghampaan pada tekanan 580-600 mmHG sehingga diperoleh ekstrak metanol daun binahong pekat.

\section{Uji Penghambatan Ekstrak Metanol Daun Binahong terhadap Pertumbuhan Koloni Jamur $R$. oryzae}

Metode yang digunakan untuk pengujian penghambatan pertumbuhan koloni jamur $R$. oryzae adalah dengan menggunakan metode poisoned food (Hubert et al., 2015; Mohana \& Raveesha, 2007). Media pertumbuhan PDA yang mengandung ekstrak metanol daun binahong dipersiapkan dengan cara menimbang ekstrak metanol pekat dan memasukkannya ke dalam media PDA hangat dalam botol Schott sesuai dengan keperluan konsentrasi yang akan diuji. Campuran media PDA dan ekstrak tersebut disiapkan dalam 5 konsentrasi uji yaitu 0,25\%, 0,5\%, 1\%, 1,5\%, dan 2\%. Perlakuan kontrol merupakan media PDA tanpa pemberian ekstrak metanol daun binahong dan campuran media PDA dengan fungisida propineb 0,3\%. Sebelumnya, antibiotik kloramfenikol (200 mg/l) ditambahkan ke dalam media PDA hangat untuk mencegah pertumbuhan bakteri.

Campuran media PDA dan ekstrak metanol daun binahong maupun fungisida kemudian dituangkan ke dalam cawan Petri steril hingga memadat yang disiapkan sebanyak empat ulangan untuk setiap perlakuan. Setelah media perlakuan memadat, biakan murni jamur $R$. oryzae $(\varnothing=5 \mathrm{~mm})$ diletakkan di tengah cawan Petri perlakuan. Cawan Petri perlakuan diinkubasikan di suhu ruang dan diamati pertumbuhan jamur $R$. oryzae pada interval waktu 24 jam dan sampai perlakuan kontrol memenuhi permukaan cawan Petri. Pengukuran diameter koloni jamur dilakukan dengan menggunakan penggaris. Pengamatan juga dilakukan terhadap karakteristik makroskopis dan mikroskopis koloni atau miselium serta hifa jamur. Kemungkinan terjadinya perubahan bentuk hifa karena pengaruh ekstrak metanol daun binahong diamati di bawah mikroskop. 
Uji Penekanan Ekstrak Metanol Daun Binahong terhadap Kejadian Penyakit Hawar Bibit pada Bibit Padi

Benih padi direndam di dalam air terlebih dahulu selama 24 jam untuk memecahkan masa dormansi benih. Benih padi yang sudah direndam selanjutnya diperam selama 24 jam di dalam wadah yang berisi kertas saring yang sudah dilembabkan untuk memacu perkecambahan benih. Benih yang sudah diperam selanjutnya direndam selama 30 menit pada masing-masing perlakuan. Setiap perlakuan menggunakan 25 benih padi untuk setiap cawan Petri dan diulang sebanyak 5 kali.

Benih yang sudah diberi perlakuan selanjutnya diinokulasi dengan patogen seperti metode yang diuraikan oleh (Ahmed et al., 2013) yaitu dengan cara menempatkan benih pada biakan murni jamur $R$. oryzae selama 3 hari. Setelah benih diinokulasiselanjutnya benih dipindahkan ke cawan Petri yang sudah dilapisi kertas saring steril lembap untuk ditumbuhkan. Pengamatan dilakukan terhadap persentase benih yang berkecambah, persentase kejadian penyakit hawar bibit, serta melihat karakteristik pertumbuhan bibit padi yaitu kesehatan bibit dan tinggi atau panjang bibit padi.

\section{HASIL DAN PEMBAHASAN}

\section{Penghambatan Pertumbuhan Koloni Jamur $R$. oryzae}

Hasil pengujian menunjukkan bahwa ekstrak metanol daun binahong dapat menghambat pertumbuhan koloni jamur $R$. oryzae terutama pada konsentrasi tinggi yaitu konsentrasi 1,5\% dan 2\% (Tabel 1). Penghambatan pertumbuhan koloni jamur $R$. oryzae tertinggi pada 5 hsi terjadi pada konsentrasi $2 \%$ yaitu sebesar $14,62 \%$ (Tabel 1). Namun demikian, penghambatan ekstrak metanol daun binahong terhadap $R$. oryzae ini tergolong lemah. Mori et al. (1995) dan Mori et al. (1997) mengkategorikan sifat aktivitas antijamur (antifungal acvity, AFA) ekstrak tanaman termasuk lemah jika persentase penghambatan yang dicapai kurang dari 25\% (lemah: 1\%-25\%; sedang: 25\%50\%; kuat: 50\%-75\%; sangat kuat: 75\%-100\%).

Tabel 1. Diameter koloni dan penghambatan pertumbuhan koloni jamur $R$. oryzae pada perlakuan ekstrak metanol daun binahong pada 3 dan 5 hsi

\begin{tabular}{lcccc}
\hline \multirow{2}{*}{ Perlakuan } & \multicolumn{2}{c}{ Pengamatan 3 hsi } & \multicolumn{2}{c}{ Pengamatan 5 hsi } \\
\cline { 2 - 5 } & $\begin{array}{c}\text { Diameter koloni } \\
(\mathrm{cm})\end{array}$ & $\begin{array}{c}\text { Penghambatan } \\
\text { pertumbuhan }(\%)\end{array}$ & $\begin{array}{c}\text { Diameter koloni } \\
(\mathrm{cm})\end{array}$ & $\begin{array}{c}\text { Penghambatan } \\
\text { pertumbuhan }(\%)\end{array}$ \\
\hline Kontrol & $3,25 \mathrm{~b}$ & - & $4,28 \mathrm{~b}$ & - \\
Propineb 0,3\% & $0,00 \mathrm{a}$ & 100 & $0,00 \mathrm{a}$ & 100 \\
Ekstrak 0,25\% & $4,90 \mathrm{~d}$ & $\mathrm{Tm}$ & $6,70 \mathrm{~d}$ & $\mathrm{Tm}$ \\
Ekstrak 0,5\% & $4,43 \mathrm{~cd}$ & $\mathrm{Tm}$ & $5,68 \mathrm{c}$ & Tm \\
Ekstrak 1\% & $4,03 \mathrm{c}$ & $\mathrm{Tm}$ & $5,40 \mathrm{c}$ & Tm \\
Ekstrak 1,5\% & $2,85 \mathrm{~b}$ & 12,31 & $4,05 \mathrm{~b}$ & 5,26 \\
Ekstrak 2\% & $2,98 \mathrm{~b}$ & 8,46 & $3,65 \mathrm{~b}$ & 14,62 \\
\hline
\end{tabular}

Keterangan : Huruf yang sama pada satu kolom dalam tabel menunjukkan data tidak berbeda nyata berdasarkan Uji Lanjut Duncan pada taraf $5 \%$. Tm = Tidak menghambat. hsi = hari setelah inkubasi.

Keefektifan ekstrak tanaman dalam konsentrasi yang tinggi dapat dihubungkan dengan kandungan kadar bahan aktif yang tinggi pada ekstrak tersebut yang mengakibatkan tingginya aktivitas penghambatan pertumbuhan patogen. Kandungan senyawa aktif yang tinggi akan menyebabkan tingginya senyawa tersebut untuk terdifusi ke dalam sel jamur (Imrosi dkk., 2012). Penekanan pertumbuhan jamur patogen tular tanah pada padi termasuk $R$. solani dan Sclerotium oryzae terjadi pada konsentrasi ekstrak tanaman antinganting yang tinggi yaitu konsentrasi 25\%, dengan hasil yang konsisten semakin tinggi konsentrasi ekstrak anting-anting menunjukkan semakin tinggi aktivitas penghambatannya (Imrosi dkk., 2012). Demikian halnya dengan hasil yang dicapai pada pengujian ini, diduga kandungan senyawa bioaktif antijamur pada ekstrak metanol daun binahong lebih banyak terkandung pada konsentrasi $2 \%$.

Perlakuan ekstrak metanol daun binahong pada konsentrasi yang lebih rendah yaitu 0,25\%, $0,5 \%$, dan $1 \%$ tidak menunjukkan adanya penghambatan pertumbuhan koloni jamur $R$. oryzae. Diduga senyawa metabolit sekunder yang bersifat antimikrob terdapat dalam jumlah yang sedikit pada konsentrasi yang rendah sehingga 
penghambatan yang terjadi juga rendah. Hasil pengujian menunjukkan bahwa perlakuan ekstrak metanol daun binahong pada konsentrasi rendah ini bahkan memiliki diameter koloni $R$. oryzae yang cenderung lebih lebar daripada perlakuan kontrol. Hal ini diduga terdapatnya senyawa pada ekstrak metanol daun binahong yang dapat merangsang pertumbuhan jamur $R$. oryzae. Dilaporkan bahwa terdapat senyawa di dalam ekstrak tanaman seperti golongan gula yang dapat merangsang pertumbuhan jamur sehingga menutupi efek penghambatannya (Bautista-Banos et al., 2003; Levin et al., 1988; Yulia dkk., 2019). Senyawa gula ini dapat mendukung pertumbuhan hampir semua spesies jamur. Anwar dkk. (2016) melaporkan binahong mengandung saponin, alkaloid, polifenol, flavonoid dan monopolisakarida termasuk L-Arabinosa, DGalaktose, L-rhamnosa, dan D-glukosa.

Pengamatan makroskopis pada koloni jamur $R$. oryzae menunjukkan adanya perbedaan karakteristik koloni jamur $R$. oryzae pada perlakuan ekstrak konsentrasi tertingi 2\% dibandingkan dengan pada perlakuan kontrol (Gambar 1). Pada perlakuan konsentrasi $2 \%$, sklerotia jamur $R$. oryzae tidak dihasilkan. Demikian juga pada konsentrasi $1,5 \%$, sklerotia yang dihasilkan sangat sedikit atau tidak dihasilkan sama sekali. Hal ini berbeda sekali dengan pembentukan sklerotia pada perlakuan kontrol dan juga perlakuan ekstrak pada konsentrasi yang lebih rendah $(0,25 \%, 0,5 \%$, dan $1 \%)$ dimana sklerotia yang dihasilkan hampir menutupi seluruh permukaan koloni jamur (Gambar 1).

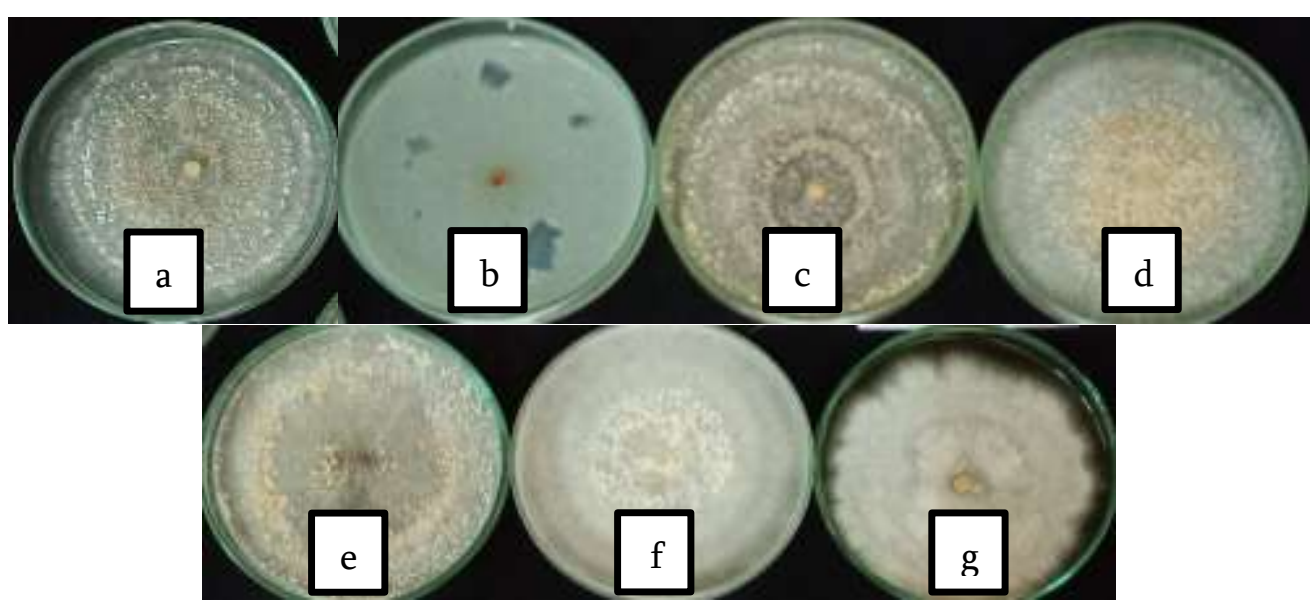

Gambar 1. Pertumbuhan koloni jamur R. oryzae pada berbagai tingkat konsentrasi ekstrak metanol daun binahong serta perlakuan kontrol. (a) Kontrol. (b) Propineb 0,3\%. (c) Ekstrak 0,25\%. (d) Ekstrak 0,5\%. (e) Ekstrak 1\%. (f) Ekstrak 1,5\%. (g) Eksrtak 2\%.

Sklerotia yang terbentuk pada perlakuan konsentrasi tinggi tidak berbentuk bulat sempurna seperti sklerotia normal yang terbentuk pada perlakuan kontrol maupun konsentrasi yang lebih rendah. Ada kecenderungan semakin rendah konsentrasi maka sklerotia yang terbentuk semakin banyak (Tabel 2). Dengan demikian, ekstrak metanol daun binahong pada konsentrasi tinggi ini meskipun memberikan penghambatan yang rendah terhadap pertumbuhan koloni jamur tetapi mampu menghambat pembentukan sklerotia jamur $R$. oryzae secara signifikan. Implikasi dari kejadian ini adalah bahwa ketersediaan sumber inokulum jamur $R$. oryzae pada perlakuan ekstrak akan menjadi jauh lebih rendah.

Tabel 2. Pembentukan sklerotia jamur $R$. oryzae pada 7 HSI

\begin{tabular}{lcccc}
\hline \multirow{2}{*}{ Perlakuan } & \multicolumn{4}{c}{ Kelimpahan sklerotia (\%) } \\
\cline { 2 - 5 } & Ulangan I & Ulangan II & Ulangan III & Ulangan IV \\
\hline Kontrol & +++ & +++ & +++ & +++ \\
Propineb 0,3\% & - & - & - & - \\
Ekstrak $0,25 \%$ & ++++ & ++++ & ++++ & ++++ \\
Ekstrak 0,5\% & ++++ & ++++ & ++++ & +++ \\
Ekstrak 1\% & +++ & +++ & +++ & ++ \\
Ekstrak 1,5\% & ++ & + & - & - \\
Ekstrak 2\% & - & - & + & +
\end{tabular}


Perlakuan fungisida propineb $0,3 \%$ pada pengujian ini menunjukkan penghambatan koloni jamur $R$. oryzae mencapai $100 \%$. Hal tersebut menunjukkan keefektifan yang tinggi fungisida propineb di dalam menghambat pertumbuhan jamur $R$. oryzae. Penghambatan pertumbuhan maupun pembentukan sklerotia $R$. oryzae pada perlakuan ekstrak metanol daun binahong diduga disebabkan oleh senyawa metabolit sekunder yang dimiliki oleh tanaman binahong. Penghambatan hanya terjadi pada pengujian konsentrasi ekstrak yang tinggi sehingga diperkirakan bahan aktif dari tanaman binahong pada konsentrasi tinggi ini mengandung jumlah dan jenis seyawa aktif yang lebih banyak.

Pengamatan terhadap karakteristik koloni atau miselium serta hifa jamur menunjukkan adanya pengaruh ekstrak metanol daun binahong terhadap kondisi miselium maupun hifa jamur $R$. oryzae. Perlakuan ekstrak metanol daun binahong menyebabkan pertumbuhan koloni jamur yang tidak rata dan miselium yang menebal. Hal ini terjadi pada perlakuan ekstrak dengan konsentrasi tinggi. Sementara itu, pengamatan secara mikroskopis terhadap hifa jamur menunjukkan terjadinya perubahan bentuk (malformasi) hifa $R$. oryzae pada perlakuan ekstrak metanol daun binahong (Gambar 2). Hifa jamur $R$. oryzae pada perlakuan kontrol terlihat normal dibandingkan dengan hifa pada perlakuan ekstrak binahong yang menunjukkan beberapa perubahan seperti hifa yang menipis, hifa yang mengeriting atau membengkok, serta hifa yang nampak kosong dengan sekat yang tidak terlihat. Hal ini menunjukkan bahwa ekstrak metanol daun binahong yang digunakan mempunyai efek langsung terjadap jamur $R$. oryzae.

Kerusakan struktur hifa pada jamur $R$. oryzae ini diduga dipengaruhi oleh kandungan senyawa aktif yang ada di dalam ekstrak binahong. Binahong dilaporkan mengandung senyawa terpenoid sementara senyawa terpenoid ini disebutkan dapat menghambat pertumbuhan dengan mengganggu proses terbentuknya membran dan atau dinding mikroorganisme sehingga membran atau dinding sel tidak terbentuk atau terbentuk tetapi tidak sempurna (Ajizah, 2004); Astuti 2011). Dengan demikian, diduga senyawa yang terkandung di dalam ekstrak binahong memengaruhi dinding sel jamur sehingga mengakibatkan malformasi hifa.
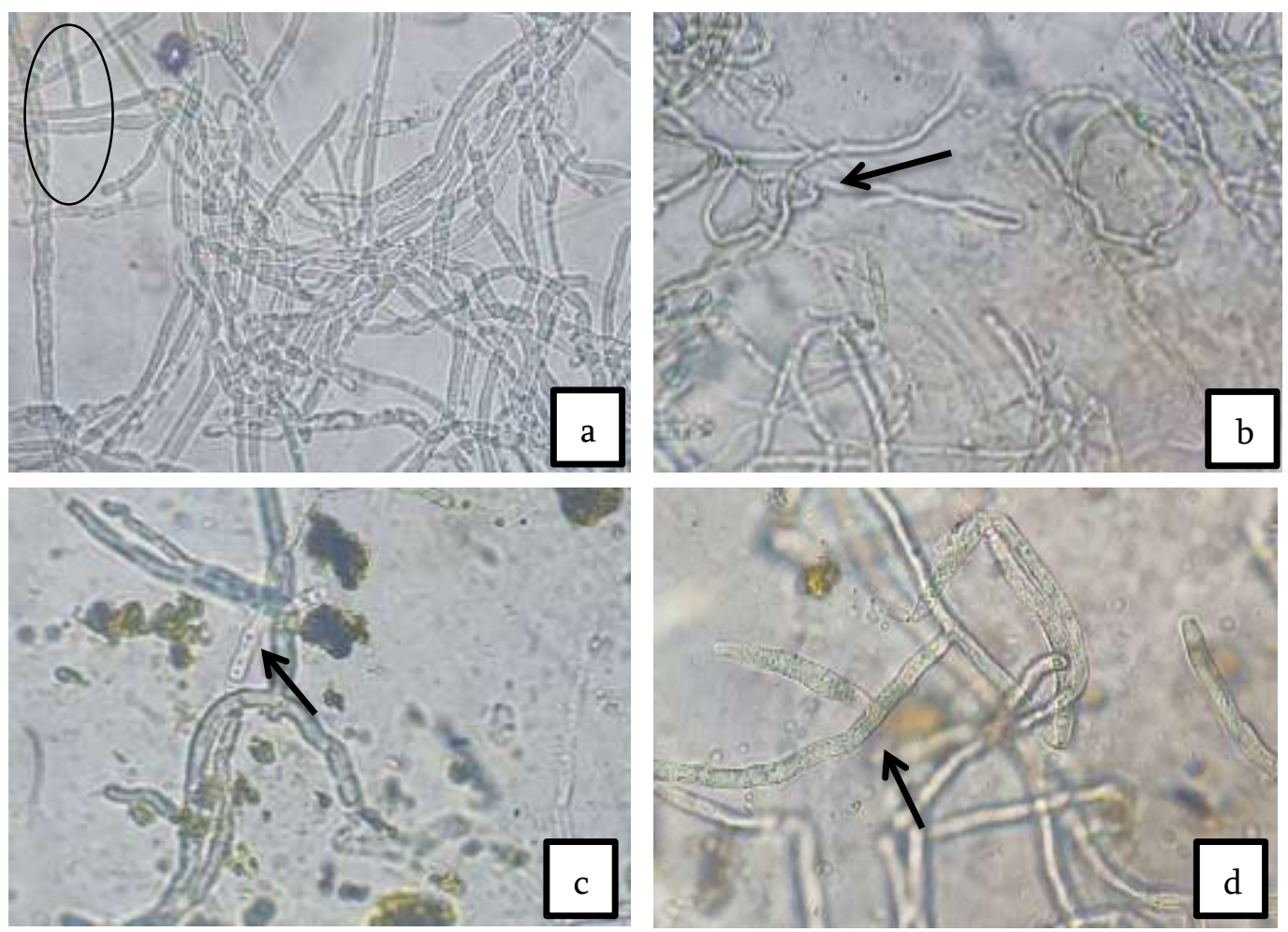

Gambar 2. Kondisi hifa jamur $R$. oryzae pada perlakuan ekstrak metanol daun binahong. (a) Hifa normal pada perlakuan kontrol. (b) Hifa yang mengeriting dan menumpuk. (c, d) Hifa yang membengkok, kosong atau menipis. 
Tanaman binahong diketahui memiliki beberapa senyawa aktif yang berperan sebagai antimikrob. Beberapa senyawa aktif tanaman binahong antara lain adalah alkaloid, flavanoid, dan saponin (Saxena et al., 2013; Djamil et al., 2017). Diduga senyawa alkaloid pada ekstrak daun binahong dapat menghambat pertumbuhan jamur $R$. oryzae karena senyawa alkaloid memiliki sifat antijamur dengan mekanisme penghambatann mendegradasi dinding sel pada jamur (Saxena et al., 2013). Senyawa flavonoid pada tanaman binahong dapat memodulasi aktivitas auksin (IAA) sehingga dapat memperkuat struktur jaringan tanaman dengan pembentukan kalus dan penutupan sistem vaskular sehigga mencegah infeksi patogen (Kurniasih et al., 2015). Sementara itu, senyawa saponin merupakan metabolit sekunder yang paling sering terdapat pada tanaman sehat dan berperan bagi ketahanan tanaman terhadap infeksi jamur dan mekanisme kerja saponin terhadap jamur yaitu berhubungan dengan kemampuan saponin untuk bersatu dengan membran sterol pada jamur (Mardiningsih et al., 2010; Astuti, 2011; Enyiukwu et al., 2014).

\section{Penekanan Kejadian Penyakit Hawar Bibit pada Perlakuan Ekstrak Metanol Daun Binahong}

Hasil pengamatan terhadap daya kecambah benih menunjukkan bahwa semua perlakuan yang diuji tidak memengaruhi daya kecambah benih secara signifikan (Tabel 3). Pada umumnya perkecambahan yang terjadi memiliki ciri-ciri perkecambahan yang baik seperti kecepatan berkecambah yang tinggi dan keseragaman perkecambahan (Halindra dkk., 2017).

Hasil pengujian aktivitas antijamur ekstrak metanol daun binahong terhadap penyakit akibat $R$. oryzae pada bibit padi menunjukkan ekstrak metanol daun binahong $2 \%$ mampu menekan kejadian penyakit busuk kecambah maupun hawar bibit padi. Pengamatan awal (2 hsi) dilakukan ketika pertama kali gejala penyakit terjadi pada kecambah padi. Pada 2 hsi, penekanan kejadian penyakit busuk kecambah padi pada perlakuan ekstrak metanol daun binahong $2 \%$ tergolong tinggi yaitu mencapai $80 \%$ (Tabel 3). Gejala infeksi $R$. oryzae pada kecambah padi di antaranya adalah bercak cokelat nekrotik pada bakal akar, perubahan warna atau busuk pada bakal akar, dan perubahan warna menjadi hitam atau busuk pada kecambah benih (Gambar 3).

Kejadian penyakit terus meningkat pada pengamatan 5 hsi di semua perlakuan kecuali pada perlakuan fungisida propineb $0,3 \%$ yang konsisten menekan kejadian penyakit sampai 100\%. Namun demikian, perlakuan ekstrak metanol daun binahong $2 \%$ masih tetap efektif menekan kejadian penyakit pada kecambah padi sampai 62,5\% (Tabel 3).

Tabel 3. Daya kecambah dan kejadian penyakit pada kecambah padi akibat infeksi $R$. oryzae pada pengujian ekstrak metanol daun binahong pada 2 hsi dan 5 hsi

\begin{tabular}{lccccc}
\hline \multirow{2}{*}{ Perlakuan } & \multicolumn{3}{c}{ Pengamatan 2 hsi } & \multicolumn{2}{c}{ Pengamatan 5 hsi } \\
\cline { 2 - 6 } & $\begin{array}{c}\text { Kejadian } \\
\text { penyakit (\%) }\end{array}$ & Penekanan (\%) & $\begin{array}{c}\text { Daya } \\
\text { kecambah (\%) }\end{array}$ & $\begin{array}{c}\text { Kejadian } \\
\text { penyakit (\%) }\end{array}$ & $\begin{array}{c}\text { Penekanan } \\
(\%)\end{array}$ \\
\hline Akuades & $4 \mathrm{~b}$ & - & $96,0 \mathrm{~b}$ & $6,4 \mathrm{~b}$ & - \\
Tween-80 0,2\% & $8,8 \mathrm{c}$ & $\mathrm{Tm}$ & $91,2 \mathrm{a}$ & $15,2 \mathrm{c}$ & $\mathrm{Tm}$ \\
Propineb 0,3\% & $0 \mathrm{a}$ & 100 & $100 \mathrm{~b}$ & $0 \mathrm{a}$ & 100 \\
Ekstrak 2\% & $0,8 \mathrm{a}$ & 80 & $99,2 \mathrm{~b}$ & $2,4 \mathrm{a}$ & 62,5 \\
\hline
\end{tabular}

Keterangan: Huruf yang sama pada satu kolom dalam tabel menunjukkan data tidak berbeda nyata berdasarkan Uji Lanjut Duncan pada taraf 5\%. Tm = Tidak Menghambat. hsi = hari setelah inkubasi.

Kejadian infeksi yang cukup berat dimana kecambah padi menjadi membusuk terutama terjadi pada perlakuan Tween-80 0,2\% (Gambar 3 dan 4). Bahkan kejadian penyakit pada perlakuan tersebut lebih tinggi dibandingkan perlakuan kontrol. Hal ini diduga penggunaan larutan Tween-80 0,2\% mempermudah penempelan inokulum jamur $R$. oryzae pada benih atau kecambah padi pada waktu inokulasi sehingga memfasilitasi terjadinya infeksi. Benih padi yang diberi perlakuan Tween-80 0,2\% dan perlakuan kontrol akuades umumnya nampak terkolonisasi oleh sklerotia jamur $R$. oryzae. Kolonisasi oleh sklerotia jamur tersebut menyebabkan benih menjadi terinfeksi pada perkembangan selanjutnya dengan menunjukkan gejala bercak nekrotik berwarna cokelat. 

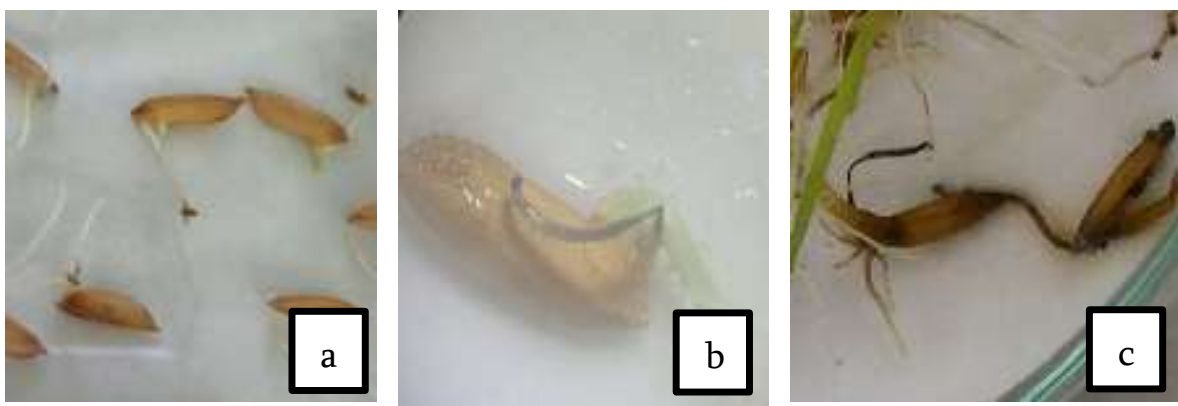

Gambar 3. Infeksi $R$. oryzae pada benih padi pada 2 hsi. (a) Nekrotik pada bakal akar. (b) Busuk pada bakal akar. (c) Busuk kecambah.
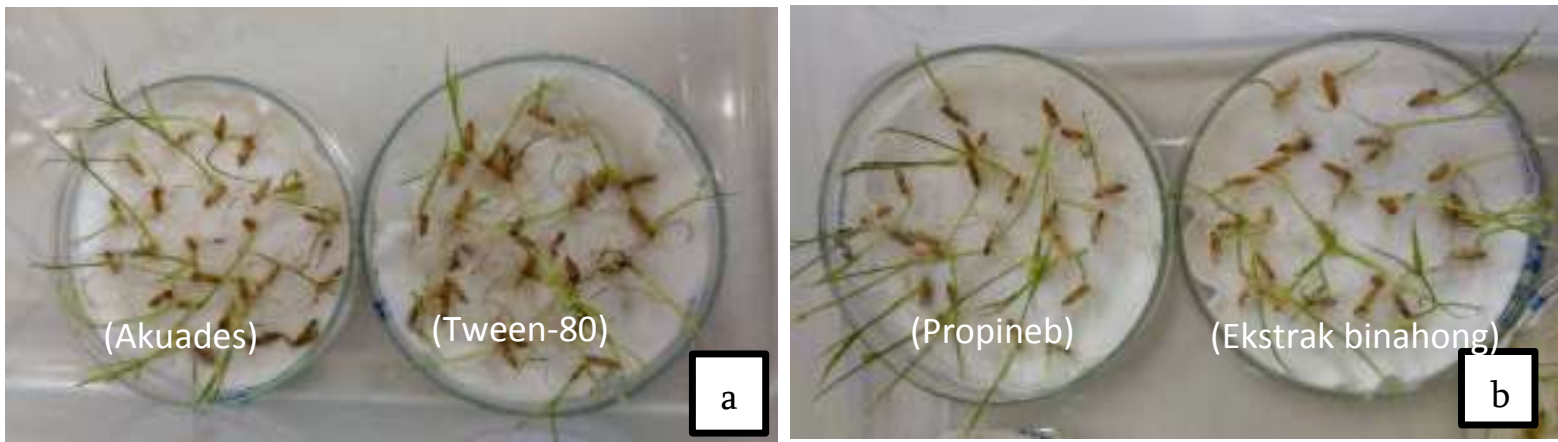

Gambar 4. Perlakuan ekstrak metanol daun binahong pada benih padi pada 5 hsi. (a) Perlakuan kontrol akuades dan Tween-80 0,2\%. (b) Perlakuan fungisida propineb 0,3\% dan ekstrak metanol daun binahong $2 \%$.

Hasil pengamatan terakhir (12 hsi) menunjukkan kejadian penyakit busuk kecambah maupun hawar bibit pada semua perlakuan berbeda nyata secara statistik (Tabel 4). Penekanan kejadian penyakit pada perlakuan ekstrak metanol daun binahong mencapai 46,2\% yang merupakan penekan tertinggi kedua setelah perlakuan fungisida propineb

0,3\% sebesar 92,3\%. Pada akhir pengamatan ini, gejala infeksi $R$. oryzae yang terjadi selain nekrosis dan busuk pada kecambah padi, nekrosis atau hawar pada bibit juga sudah berkembang (Gambar 5). Kecambah atau bibit padi pada beberapa perlakuan (terutama Tween-80 0,2\% dan kontrol akuades) sudah menghitam dan membusuk.

Tabel 4. Kejadian penyakit pada bibit padi akibat infeksi $R$. oryzae dan panjang bibit padi pada pengujian ekstrak metanol daun binahong pada 12 hsi

\begin{tabular}{lccc}
\multicolumn{1}{c}{ Perlakuan } & & & \multirow{2}{*}{ Panjang bibit $(\mathrm{cm})$} \\
\cline { 2 - 3 } & Kejadian penyakit (\%) & Penekanan $(\%)$ & $4,7 \mathrm{~b}$ \\
Akuades & $31,2 \mathrm{c}$ & - & $3,9 \mathrm{a}$ \\
Tween-80 0,2\% & $50,4 \mathrm{~d}$ & Tm & $9,6 \mathrm{~d}$ \\
Propineb 0,3\% & $2,4 \mathrm{a}$ & 92,3 & $7,3 \mathrm{c}$ \\
\hline
\end{tabular}

Keterangan: Huruf yang sama pada satu kolom dalam tabel menunjukkan data tidak berbeda nyata berdasarkan Uji Lanjut Duncan pada taraf 5\%. Tm = Tidak Menghambat. hsi = hari setelah inkubasi.

Hasil pengamatan menunjukkan adanya kolonisasi $R$. oryzae pada perlakuan ekstrak metanol daun binahong $2 \%$ tetapi tidak menunjukkan gejala bibit padi yang terinfeksi. Dengan demikian, perlakuan benih padi dengan ekstrak ini nampaknya dapat menghambat infeksi patogen $R$. oryzae pada benih atau bibit padi. Perubahan warna (diskolorisasi) terjadi pada beberapa benih padi pada perlakuan ekstrak binahong tetapi bukan karena terinfeksi (bergejala) melainkan diduga karena adanya kejadian fitotoksik yang disebabkan oleh penggunaan ekstrak binahong pada konsentrasi yang cukup tinggi. Kejadian fitotoksik ini diduga dapat meningkatkan kejadian infeksi $R$. oryzae pada benih padi. Kolonisasi jamur $R$. oryzae hampir tidak terjadi pada perlakuan fungisida propineb 0,3\% pada pengamatan terakhir. 

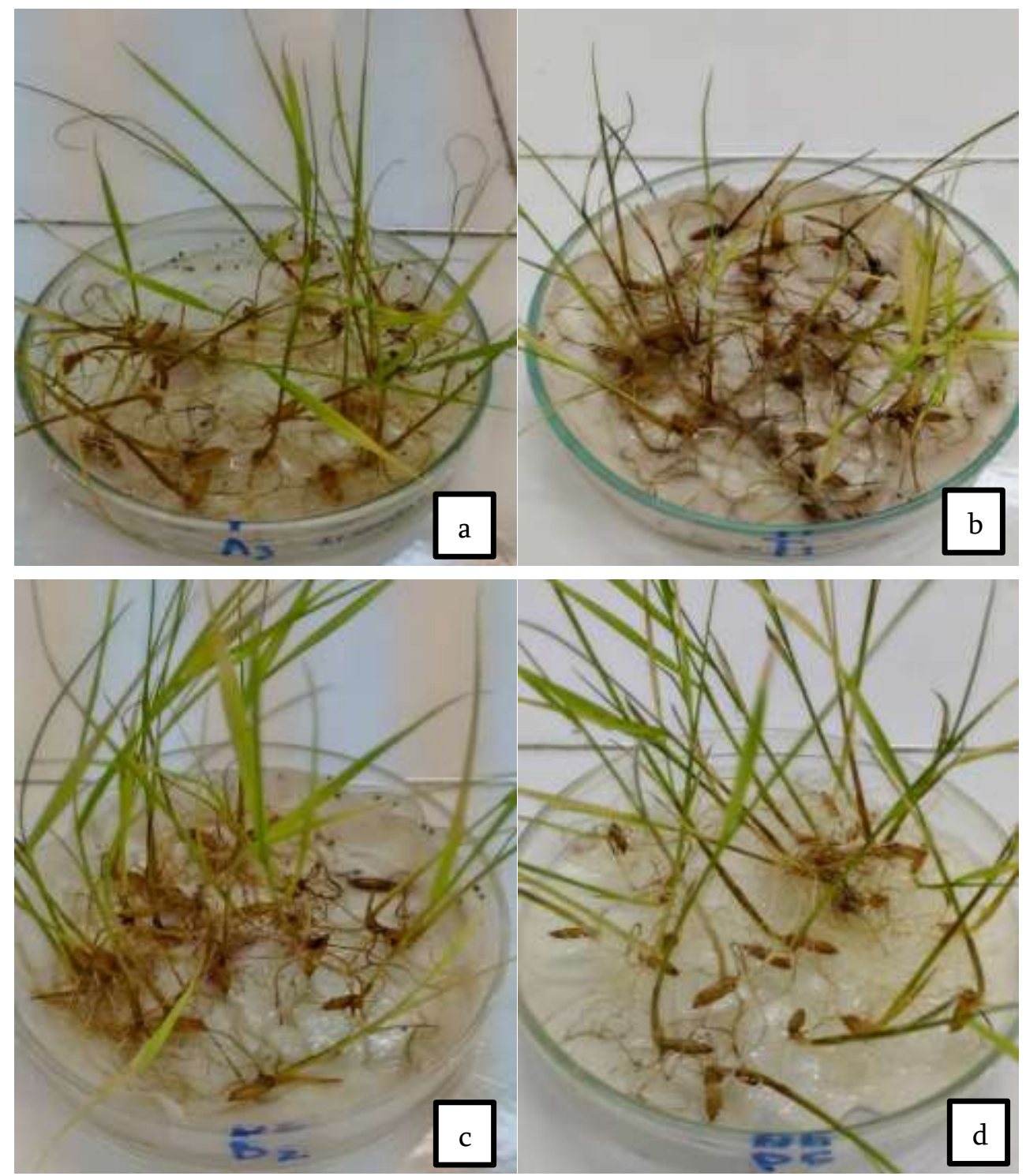

Gambar 5. Perlakuan benih padi dengan ekstrak metanol daun binahong pada 12 HSI. (a, b) Perlakuan kontrol akuades dan Tween-80 0,2\% yang menunjukkan bibit yang terinfeksi serta kolonisasi dan massa sklerotia jamur $R$. oryzae. (c) Perlakuan ekstrak 2\% yang menunjukkan benih terinfeksi, diskolorisasi dan sedikit sklerotia jamur $R$. oryzae. (d) Perlakuan fungisida propineb 0,3\% yang menunjukkan benih yang tidak terinfeksi dan tanpa massa sklerotia jamur $R$. oryzae.

Infeksi jamur $R$. oryzae mengakibatkan terhambatnya pertumbuhan benih atau bibit padi (Gambar 6). Infeksi yang berat pada perlakuan Tween-80 0,2\% mengakibtkan rata-rata panjang bibit padi hanya $3,9 \mathrm{~cm}$ (Tabel 4). Infeksi jamur $R$. oryzae yang rendah pada perlakuan fungisida propineb $0,3 \%$ menghasilkan rata-rata panjang bibit padi tertinggi sebesar $9,6 \mathrm{~cm}$. Sementara itu, pada perlakuan ekstrak metanol daun binahong 2\% mencapai rata-rata panjang bibit padi sebesar 7,3 cm yang lebih tinggi dan berbeda nyata dengan kontrol akuades sebesar $4,7 \mathrm{~cm}$.
Perlakuan benih padi dengan ekstrak metanol daun binahong di dalam penelitian ini memberikan penekanan terhadap kejadian penyakit pada benih yang kemudian memengaruhi karakteristik pertumbuhan bibit padi. Beberapa penelitian sebelumnya melaporkan bahwa kandungan senyawa bioaktif di dalam tanaman binahong, tidak hanya memiliki sifat antimikrob saja tetapi juga memiliki sifat yang memengaruhi kesehatan dan ketahanan sel seperti sifat antioksidan (Anwar \& Soleh dkk., 2016; Ekaviantiwi dkk., 2013). 


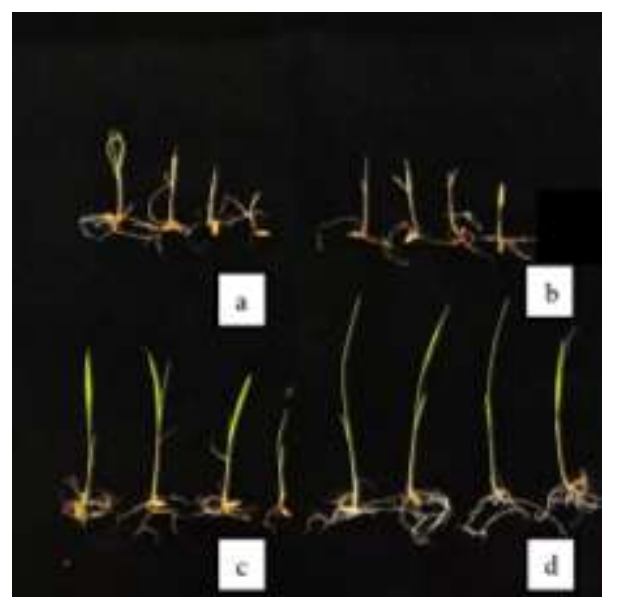

Gambar 6. Pertumbuhan atau panjang bibit padi pada pengujian ekstrak metanol daun binahong. (a) Akuades steril. (b) Tween-80 0,2\%. (c) Ekstrak binahong 2\%. (d) Fungisida propineb 0,3\%.

Pemanfaatan ekstrak tanaman untuk mengendalikan patogen tanaman padi sudah banyak dilaporkan. Ekstrak daun sirih dengan pelarut etanol terbukti dapat menekan pertumbuhan patogen Xanthomonas oryzae dengan terbentuknya zona bening atau zona penghambatan yang besar pada konsentrasi 2,5\% (Amrulloh, 2008). Penelitian lain menyebutkan bahwa penggunaan ekstrak gulma anting-anting (Achalypha indica L.) memiliki potensi sebagai antijamur beberapa patogen padi seperti $R$. solani, Cercospora oryzae, Sclerotium oryzae, dan Pyricularia oryzae secara in vitro pada kisaran konsentrasi 1\%-25\% dengan penghambatan pertumbuhan jamur tertinggi sebesar $69,70 \%$ pada konsentrasi 25\% (Imrosi et al., 2012).

Kemampuan tanaman binahong sebagai bahan antimikrob diperkirakan karena kandungan senyawa bioaktif di dalam tanaman binahong. Tanaman binahong dilaporkan memiliki kandungan senyawa aktif seperti saponin, alkaloid, terpenoid dan flavonoid (Astuti, 2011). Pada penelitian sebelumnya, ekstrak air daun binahong pada konsentrasi $6,25 \%$ mampu menghambat pertumbuhan koloni jamur Colletotrichum spp. dengan penghambatan sebesar 66,88\% (Yulia dkk., 2016). Pada konsentrasi yang sama, ekstrak air daun binahong dapat menghambat pertumbuhan jamur Fusarium oxysporum f.sp. lycopercisi isolat tomat sebesar 38,67\% serta menghambat perkecambahan konidia jamur sebesar 43,44\% (Widiantini dkk., 2016). Namun demikian, ada indikasi konsentrasi ekstrak yang tinggi akan menstimulasi pertumbuhan jamur pada pengujian-pengujian tersebut. Beberapa penelitian ekstrak metanol tanaman dilaporkan efektif dalam mengendalikan patogen tanaman. Ekstrak metanol daun salam pada konsentrasi 2-5\% dan daun jeruk purut pada semua konsentrasi 1-5\% secara in vitro efektif menghambat perkecambahan atau pertumbuhan konidia jamur Fusarium oxysporum (Noveriza \& Miftakhurohmah, 2010). Penelitian Aulifa dkk. (2014) yang menggunakan konsentrasi ekstrak metanol 0,5\% dan 1\% beberapa jenis tanaman menunjukkan hasil aktivitas antijamur ekstrak-ekstrak tersebut terhadap Phytophthora palmivora dengan penghambatan tertinggi mencapai 89,85\%. Pengujian perlakuan benih padi dengan ekstrak metanol daun binahong menunjukkan ekstrak metanol daun binahong memengaruhi kesehatan benih padi serta menekan perkembangan penyakit hawar bibit akibat $R$. solani hingga $100 \%$ pada konsentrasi $2 \%$ (Yulia \& Widiantini, 2018).

\section{SIMPULAN}

Berdasarkan hasil pengujian keefektifan ekstrak metanol daun binahong terhadap patogen $R$. oryzae pada tanaman padi dapat diambil kesimpulan sebagai berikut:

1. Ekstrak metanol daun binahong pada konsentrasi 2\% mampu menghambat pertumbuhan koloni jamur $R$. oryzae dengan tingkat penghambatan yang lemah sebesar $14,62 \%$ tetapi memiliki penghambatan yang tinggi terhadap pembentukan sklerotia jamur $R$. oryzae.

2. Perlakuan benih padi dengan ekstrak metanol daun binahong konsentrasi 2\% dapat menekan kejadian penyakit hawar bibit akibat infeksi $R$. 
oryzae pada kecambah benih atau bibit padi dengan penekanan tertinggi sebesar $46,2 \%$.

\section{UCAPAN TERIMAKASIH}

Terimakasih disampaikan kepada Universitas Padjadjaran atas dana penelitian Hibah Internal Unpad (HIU) melalui skema Riset Fundamental Unpad (RFU) untuk pelaksanaan penelitian ini.

\section{DAFTAR PUSTAKA}

Ahmed, M, M Hossain, K Hassan, and CK Dash. 2013. Efficacy of different plant extract on reducing seed borne infection and increasing germination of collected rice seed sample. Univers. J. Plant Sci. 1(3): 66-73.

Ajizah, A. 2004. Sensitivitas Salmonella typhimurium terhadap ekstrak daun Psidium guajava L. Bioscientie. 1(1): 31-38.

Amrulloh, I. 2008. Uji Potensi Ekstrak Daun Sirih (Piper betle L.) sebagai Antimikroba terhadap Bakteri Xanthomonas oryzae pv. oryzae dan jamur Fusarium oxysporum. Skripsi. Universitas Islam Malang. Malang.

Anwar, TM, dan TU Soleha. 2016. Manfaat daun binahong (Anredera cordifolia) sebagai terapi acne vulgaris. Majority. 5(5): 179-183.

Astuti, SM. 2011. Determination of saponin compound from Anredera cordifolia (Ten) Steenis plant (binahong) to potential treatment for several diseases. Journal of Agricultural Science. 3(4): 224-232.

Aulifa, DL, INP Aryantha, dan Sukrasno. 2014. Aktivitas anti jamur ekstrak metanol dari tumbuhan rempah-rempahan. Jurnal Ilmuilmu Hayati dan Fisik. 16(1): 10-15.

Aye, SS, and M Matsumoto. 2012. Pathogenicity and symptom expressions of Rhizoctonia solani, $R$. oryzae and $R$. oryzae-sativae to some commercial cultivars of rice in Myanmar. 45(16): 1991-1996.

Aye, SS, YY Myint, T Lwin, and M Matsumoto. 2009. Rhizoctonia oryzae-sativae, causal agent of aggregate sheath spot disease of rice, found in Myanmar. Plant Pathol. 58(6): 1173.

Bautista-Banos, S, M Hernandez-Lopez, E BosquezMolinab, and CL Wilson. 2003. Effects of chitosan and plant extracts on growth of Colletotrichum gloeosporioides, anthracnose levels and quality of papaya fruit. Crop Protection. 22: 1087-1092.
Djamil, R, W. Winarti, S Zaidan, and S. Abdillah. 2017. Antidiabetic activity of flavonoid from binahong leaves (Anredera cordifolia) extract in alloxan induced mice. J Pharmacogn Nat Prod. 3(2): 139-142.

Ekaviantiwi, TA, E Fachriyah, dan D Kusrini. 2013. Identifikasi asam fenolat dari ekstrak etanol daun binahong (Anredera cordifolia (Ten.) Stennis) dan uji aktivitas antioksidan. Chem Info. 1(1) : 283-293.

Enyiukwu, DN, AN Awurum, CC Ononuju, and JA Nwaneri. 2014. Significance of characterization of secondary metabolites from extracts of higher plants in plant disease management. International Journal of Advance Agricultural Research. 2: 8-28.

Groth, D and C. Hollier. 2010. Seedling Blight of Rice. Lousiana Plant Pathology - Disease Identification and Management Series. LSU AgCentre Research and Extension. Pub. No. 3117. Tersedia Online pada www.lsuagcentre.com. Diakses 25 September 2019.

Guo, Q A. Kamio, BS Sharma, Y Sagara, M Arakawa, and K Inagaki. 2006. Survival and subsequent dispersal of rice sclerotial disease fungi, Rhizoctonia oryzae and Rhizoctonia oryzae-sativae, in paddy fields. Plant Dis. 90: 615-622.

Halindra, YM, ERP Wardoyo, dan R Linda. 2017. Perkecambahan benih padi (Oryza sativa L.) lokal asal Kalimantan Barat berdasarkan tingkat salinitas. Protobiont. 6: 295-302.

Hubert, J, RB Mabagala, and DP Mamiro. 2015. Efficacy of selected plant extracts against Pyricularia grisea, causal agent of rice blast disease. American Journal of Plant Sciences. 3(2): 602-611.

Imrosi, AN, PA Mihardjo, dan M Hoesain. 2012. Pemanfaatan ekstrak gulma anting-anting (Acalypha indica L.) sebagai antifungal beberapa patogen padi secara in vitro. Berkala Ilmiah Pertanian. 1(1): 1-4.

Kumalasari, E, dan N Sulistyani. 2011. Aktivitas antifungi ekstrak etanol (Anredera cordifolia (Tenore) Steen) terhadap Candida albicans serta skrining fitokimia. Jurnal Ilmiah Kefarmasian. 1(2): 51-62.

Kurniasih, N, M Kusumiyati, Nurhasanah, RP Sari, dan $\mathrm{R}$ Wafdan. 2015. Potensi daun sirsak (Annona muricata Linn), daun binahong (Anredera cordifolia (Ten) Steenis), dan daun 
benalu mangga (Dendrophthoe pentandra) sebagai antioksidan pencegah kanker. 9(5):162-184.

Lanoiselet, VM, EJ Cother, and GJ Ash. 2007. Aggregate sheath spot and sheath spot of rice. Crop Protection. 26: 799-808.

Lanoiselet, LA, EJB. Cother, GJA. Ash, JDIA Harper, and A. Farrer. 2005. Yield loss in rice caused by Rhizoctonia oryzae and $R$. oryzae-sativae in Australia. Australian Plant Pathologhy Society. 34: 175-179.

Levin, H, R Hazenfratz, J Friedman, D Palevitch, and M Perl. 1988. Partial purification and some properties of an antibacterial compound from Aloe vera. Phytotherapy Research. 2(2): 67-69.

Mardiningsih, TL, C Sukmana, N Tarigan, dan S Suriati. 2010. Efektivitas insektisida nabati berbahan aktif azadirachtin dan saponin terhadap mortalitas dan intensitas serangan Aphis gossypii Glover. Balittro. 21(2): 171183.

Mohana, DC, and KA Raveesha. 2007. Anti-fungal evaluation of some plant extracts against some plant pathogenic field and storage fungi. Journal of Agricultural Technology. 4(1): 119-137.

Mori, M, M Aoyama, S Doi, A Kanetoshi, and T Hayashi. 1995. Antifungal activity of bark extracts of conifers. Holz als Roh-und Werkstoff. 53(2): 81-82.

Mori, M, M Aoyama, S Doi, A Kanetoshi and T Hayashi. 1997. Antifungal activity of bark extract of deciduous trees. Holz als Roh-und Werkstoff. 55(2-4): 130-132.

Nagaraj, BT, G Sunkad, P Devanna, MK Naik, and MB Patil. 2019. Characterization of Rhizoctonia species complex associated with rice sheath disease in Karnataka. Agricultural Research. 8(2): 191-196.

Noveriza, R, dan Miftakhurohmah. 2010. Efektivitas Ekstrak Metanol Daun Salam (Eugenia polyantha) dan Daun Jeruk Purut (Cytrus histrix) Sebagai Antijamur Pada Pertumbuhan Fusarium oxysporum. Jurnal Littri. 16(2): 6-11.

Paulitz, TC, H Zhang, and RJ Cook. 2003. Spatial distribution of Rhizoctonia oryzae and rhizoctonia root rot in direct-seeded cereals. Journal Plant Pathologhy. 303: 295-303.

Rimporok, S, BJ Kepel, dan KV Siagian. 2015. Uji efektivitas ekstrak daun binahong (Anredera cordifolia (Ten.) Steenis) terhadap pertumbuhan Streptococcus mutans secara in vitro. Pharmacon Jurnal Ilmiah Farmasi. 4(4): 15-21.

Saxena, M, J Saxena, R Nema, D Singh, and A Gupta. 2013. Phytochemistry of medicinal plants. J. Pharmacogn. Phytochem. 1(6): 13-14.

Widiantini, F, E Yulia, dan Riska. 2016. Uji keefektifan ekstrak air daun binahong (Anredera cordifolia [Ten.] Steenis) terhadap patogen penyebab penyakit layu fusarium (Fusarium oxysporum Schlecht. f.sp. lycopersici [Sacc.] Synd. et Hans.) pada tomat. Prosiding Seminar Nasional Perkumpulan Agroteknologi/ Agroekologi Indonesia. Universitas Sebelas Maret. Hlm. 503-507.

Yulia, E, dan F Widiantini. 2018. Ekstrak tanaman binahong sebagai pengendali penyakit hawar pelepah daun padi. Jurnal Fitopatologi Indonesia. 14 (4) : 138-144.

Yulia, E, F Widiantini, A Purnama, dan I Nurhelawati. 2016. Keefektifan ekstrak air daun binahong terhadap patogen penyebab penyakit antraknos pada cabai. Prosiding Seminar Nasional Perkumpulan Agroteknologi/Agroekologi Indonesia. Universitas Sebelas Maret. Hlm. 499-502.

Yulia, E, SRD Syafira, F Widiantini, dan W Kurniawan. 2019. Assessment of Sarocladium oryzae growth inhibition, the causal agent of rice sheath rot disease, using methanol extract of binahong leaves. Jurnal Cropsaver. 2(1): 15-21. 